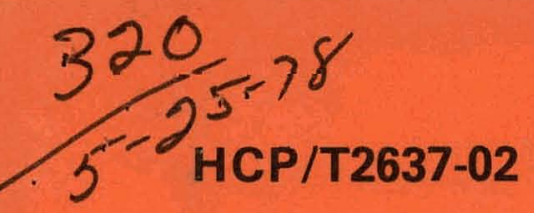

\title{
Definition of Scale Model Slurry Mixing/Distribution Facility
}

May 1978

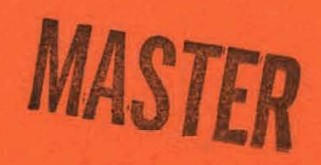

Prepared For

U.S. Department of Energy

Assistant Secretary For Energy Technology

Division of Power Systems

Under Contract No. EX-77-C-01-2637 


\section{DISCLAIMER}

This report was prepared as an account of work sponsored by an agency of the United States Government. Neither the United States Government nor any agency Thereof, nor any of their employees, makes any warranty, express or implied, or assumes any legal liability or responsibility for the accuracy, completeness, or usefulness of any information, apparatus, product, or process disclosed, or represents that its use would not infringe privately owned rights. Reference herein to any specific commercial product, process, or service by trade name, trademark, manufacturer, or otherwise does not necessarily constitute or imply its endorsement, recommendation, or favoring by the United States Government or any agency thereof. The views and opinions of authors expressed herein do not necessarily state or reflect those of the United States Government or any agency thereof. 


\section{DISCLAIMER}

Portions of this document may be illegible in electronic image products. Images are produced from the best available original document. 


\section{Definition of Scale Model Slurry Mixing/Distribution Facility}

May 1978

Prepared For

U.S. Department of Energy

Assistant Secretary For Energy Technology

Division of Power Systems

Washington, D.C. 20545

Prepared By

Arthur G. McKee \& Company

Under Contract No. EX-77-C-01-2637

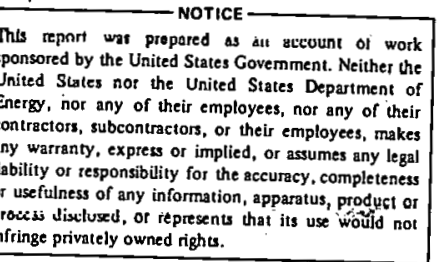




\section{NOTICE}

This report was prepared as an account of work sponsored by the United States Government. Neither the United States nor the United States Department of Energy, nor any of their employees, makes any warranty, expiess or implied, or assumes any legal liability or responsibility for the accuracy, completeness, or usefulness of any information, apparatus, product, or process disclosed, or represents that its use would not infringe privately owned rights. Reference herein to any specific commercial product, process, or service by trade name, mark, manufacturer, or otherwise, does not necessarily constitute or imply its endorsement, recommendation, or favoring by the United States Government or any agency thereof. The views and opinions of authors expressed herein do not necessarily state or reflect those of the United States Government or any agency thereof. 
DEFINITION OF SCALE MODEL

SLURRY MIXING/DISTRIBUTION FACILITY

TABLE OF CONTENTS

I. INTRODUCTION

II. PLANT AND MODEL DESIGN BASIS

A. Scope of Engineering Effort

B. Model Guidelines

111. PROCESS DESCRIPTION

A. Material Flow

1. Incoming Raw Material Handling

2. Fuel Preparation System

3. Product Loadout

4. Process Design Summary

B. Operationa1 Requirements

1. Incoming Raw Material Handling

2. Fuel Preparation

3. Product Loadout

IV. MAJOR EQUIPMENT LIST

V. CONCEPTUAL URAWINGS 
I. INTRODUCTION

The United States Department of Energy (DOE), formerly the Energy Research and Development Administration (ERDA), desires to develop a coal-in-oil slurry combustion concept for demonstration in the industrial andutility sectors. Commensurate with this objective, this document is intended to present a definition of a scale model representing a slurry mixing/distribution facility.

Motivation for the DOE Coal-0il Slurry Program resulted from: dwindling domeștic oil and natural gas supplies, an abundant national reserve of coal, advanced coal conversion systems not being available in the near future, and the potential for utilization of coal-oil slurry fuel systems in the near future. Thus, coal-oil slurry systems can extend the nations's fuel supplies and possibly provide emergency preparedness in the event of an embargo.

The $1 / 8^{\prime \prime}=1^{\prime}-0^{\prime \prime}$ scale model described herein depicts a mock commercial coal-in-oil slurry mixing and distribution type plant. The model represents a suggested facility for the optimization and marketing of a stable coal-oil slurry to multiple users under a single specification. The raw materials are assumed to be coal, fuel oil and a stabilizer additive to keep the slurry in suspension during transit and storage. The model reflects a method for handling coal using railival cars which are bottom dumped to a below grade track hopper, weighed and transported to a stockpile by belt conveyors. Stockpile reclaim is accomplished by a front-end loader and the coal is conveyed to the fuel preparation building. There it is pulverized and mixed with fuel oil and a stabilizer. The slurry produced is then tank stored to await shipment to the user by railroad tank car or truck.

The plant sizing and model construction was conceived to provide a portable model unit with carrying case and all necessary hardware for one to two man cartage. The primary intent of the scale model was to provide a "showcase sales tool," representing one possible scheme for a coal-oil mixture manufacturing and distribution facility. 


\section{PLANT AND MODEL DESIGN BASIS}

\section{A. Scope of Engineering Effort}

The conceptual design drawings, attached under Section V, wrere developed using the following basic guidelines:

1. The selection and sizing of the process equipment was made for a mock commercial facility capable of supplying 64,000 gallons/day of a coal-oilmixture of a 50 percent by weight coa1 concentration.

2. The flow sheet and general arrangement drawings were developed sufficiently to ensure a proper material flow and balance and a workable and practical plant layout with adequate plant equipment detail to allow modeling.

3. In general, only major material handling equipment, process equipment and major structures were developed.

4. The mock commercial plant includes facilities for:

a. Receipt of the Raw Materials - coal, fuel oil and a stabilizer received via railroad and/or truck.

b. Raw Material Storage - exposed coal stockpile; fuel oil vertical tank storage; stabilizer horizontal tank storage.

c. Raw Material Reclaiming Systems - coal reclaimed by frontend loader, fuel oil by pumping and stabilizer by pumping.

d. Coal Grinding and Slurry Mixing

e. Product Storage - vertical tanks prior to shipment to the user. 
f. COM Loadout - station was provided for railroad tank car or truck loading along with associated pumping systems.

\section{B. Mode1 Guidelines}

Due to the model scale size $\left(1 / 8^{\prime \prime}=1^{\prime}-0^{\prime \prime}\right)$, plant design and mndoling efforts were restricted to basic material handling and procug; flow. The mndrl reflects all major process equipment, main transport piping with pumps, as well as major support structures and buildings. Some landscaping was also included. The model was designed and supplied with carrying case and all necessary hardware for one to two man handling.

Auxiliary and support systems such as dust collection, dust suppression fire protection, compressed air system, underground, etc. were disregarded. However, facilities such as an office, control room, locker room and,a,motor control center are showrion the model. 


\section{PROCESS DESCRIPIION}

\section{A. Material Flow (refer to Flow Diagram SK92177-1)}

1. Incoming Raw Material Handling

Run-of-mine coal is received in 100 ton bottom dump railroad cars "100. Nine cars per week would be required to supply the $24 \mathrm{hr} /$ day operating plant. The cars are dumped, one at a time, over the underground track hopper 非103. The car unloading is assisted by the use of the overhead car shaker and car spotting is accomplished by the use of the capstan type car puller. The track hopper will also accomodate lruck unloading. The coal is removed from the track hopper by two vibrating pan feeders, each at a rate of $75 \mathrm{tph}$, which discharge to the 24 " wide belt conveyor 非105. The coal is weighed in transit to the stockpile by the belt scale 1106 mounted on conveyor \#105. The 24" rail mounted radial stacker conveyor 非107 delivers the coal at a rate of 150 tph to the stockpile. At full capacity, the stockpile is $15 \mathrm{ft}$ high and has sufficient storage for 14 days of plant operation. As an alternate, the radial stacker may be positioned to by-pass the stockpile and deliver incoming coal directly for processing by way of the reclaim hopper $\$ 109$.

No. 6 fuel oil is received by railroad tank car or tank truck and pumped to the two fuel oil storage tanks 1134 , which togcther contain a one week operational supply. Pumping to the tanks is accomplished at the rate of $120 \mathrm{gpm}$.

The stabilizer additive required for the process is delivered by truck and is pumped to storage tank $\|_{124}$, which has a capacity of about 2200 gallons. This capacity is sufficient to eupply the plant operations for about one week. 


\section{Fuel Preparation System}

Slurry production is initiated by reclaiming coal using the 6 cubic yard front-end loader 非108, which discharges to tive reclaim hopper \#109. Vibrating feeder 非10, under the reclaim hopper, discharges onto the inclined 36" flexible sidevall conveyor $\#_{112}$. The metal detector $k_{111}$, mounted over the flexible sidewa11 conveyor, is intended to stop the conveyor in the event of rrany metal contaminants, to allow nanual removal.

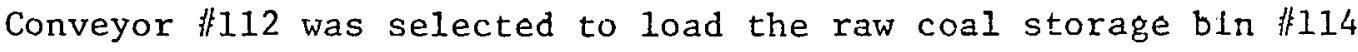
at a rate of $150 \mathrm{tph}$. The coal 1s weighed as it is metered out of the bin at a controlled rate of $5 \mathrm{tph}$, utilizing the $18^{\prime \prime}$ belt weigh feeder \#116. The weigh feeder conveys the coal to one of two coal pulverizers (bowl mills), accomplished through a diverter type chute with a "flop" gate. As designed, only one pulverizer is to be on-line, while the other is on stand-by. This will allow plant operation while one mill is shutdown for maintenance. The function of the mills is to pulverize the coal to about 80 percent less than 200 mesh.

Each soal pulverizer has a rated capacity of 13,600 1bs/hs. The pressure through the mill is generated by the mill fan \#119. This air flow carries the coal upwards through the mill to the air separator \$120. As the coal particles are transported upwards by the air stream, the larger and heavier particles fall back into the m111 to be further reduced lil size. Tho coal parllules lransported to the air separator will drop into the hopper portion of the dis separacur. Some vry fine airhorne coal particles w1ll be transported back to the pulverizer along with the recycled air, by way of the mill fan.

The rotory valve $\$ 121$ feeds pulverized coal from the air separator to the weigh auger $\$ 122$, which delivers 5 tph to the mix tank " 126 , for mixing with the other raw process materials. 
The \#6 fuel oil is pumped from either of the oil storage tanks 134 to the mix tank at a rate of $45 \mathrm{gpm}$ using either of the fuel oil pumps \#135. Simultaneously, the additive is pumped from the additive storage tank 1124 to the mix tank at a rate of $60 \mathrm{gpm}(0.5 \%$ of total mix assumed) using pump 非 125 . The mixing is then accomplished by using an agitator, powered by a variable speed drive. As mixing is completed, the stable slurry is pumped from the mix tank to either of the two slurry storage tanks 非128.

Slurry pumping to storage tanks is provided at a rate of $45 \mathrm{gpm}$ using pither ono of the sluiny pumps il127. The slurry product storage capacity is about 64,500 gallons per tank or a storage of one day's plant production each. Both of the slurry storage tanks are equipped with an agitator.

\section{Product Loadout}

The coal oil. mixture is loaded into railroad tank cars or trucks. An operator's platform has been appropriately provided for pumping slurry product using pump $\$ 130$ at a rate of $120 \mathrm{gpm}$ from the slurry tanks $\# 128$.

4. Process Design Summary

a. Raw Material Requirements

Coal - 5 tons $/ \mathrm{hr}, 120$ tons/day

\#6 fuel oil - $1177 \mathrm{gal} / \mathrm{hr}, 28,250 \mathrm{gal} / \mathrm{day}, 673 \mathrm{barrels} / \mathrm{day}{ }^{*}$

Additive - $30 \mathrm{gal} / \mathrm{hr}, 720 \mathrm{gal} / \mathrm{day}, 17 \mathrm{barrels}_{\mathrm{day}}{ }^{*}$ 
b. Product Yield

$$
\begin{aligned}
& \text { COM }-2700 \text { gal/hr, 64,000 gal/day, } 1524 \text { barrcls/day }{ }^{*} \\
& * 42 \text { gallons = } 1 \text { barrel }
\end{aligned}
$$

\section{B. Operational Requirements}

It is cotimated that the plant process und material flow wnuld require the following operating schedule and manpower:

\section{Incoming Raw Material Handling}

The incoming coal and additive materials would require two operators on a single 8-hour shift per week. The 非 fuel oil receiving would be accomplished on a three 8-hour shift per week basis. The men required in this area could also serve in the product loaduul area, as required.

\section{Fuel Preparation}

Coal grinding and mixing activities would be on a continuous basis, three shifts per day, handled by one operator each shift.

\section{Product Loadout}

It is judged that the operating function in this area rould be accomplished during one 8-hour shift pei day, 3 duys pier week, by the same two operators handling incoming raw materials. 


\section{MAJOR EQUIPMENT LIST}

PRGJECT: DEFIVITION OF MODEL - SLURRY MIXING/DISTRIBUTION FACILITY

\begin{tabular}{|c|c|c|c|}
\hline $\begin{array}{l}\text { IIEM } \\
\text { NO. }\end{array}$ & $\begin{array}{l}\text { NO. } \\
\text { REQ'D. }\end{array}$ & DESCRIPTIOM & EQUIPMENT DATA \\
\hline 100 & $9 /$ wk & Railroad cars & 100 ton; bottom dump \\
\hline $1 \mathrm{Cl}$ & 1 & Car pulier & $10,0001 \mathrm{~b}$ pu11 capstan type; $10 \mathrm{hp}$ \\
\hline 102 & 1 & Car shaker & $\begin{array}{l}5 \text { hp shaker with } 71 / 2 \text { hp motorized lift of } 10,000 \mathrm{lb} \\
\text { capacity }\end{array}$ \\
\hline 103 & 1 & Track hopper & 125 ton capacity \\
\hline $10_{4}^{\prime}$ & 2 & Vibrating feeder & Size $18^{\prime \prime} \times 5^{\prime}-0^{\prime \prime} ; 3 / 4$ hp each; 75 tph each \\
\hline 105 & 1 & Belt conveyor & $24^{\prime \prime}$ belt; $15 \mathrm{hp} ; 150 \mathrm{tph}$ \\
\hline 106 & 1 & Belt scale & In transit weighing of incoming coal \\
\hline $10 ?$ & 1 & Radial stacker conveyor & $\begin{array}{l}24 \text { " belt; rail mounted; power travel; belt speed }=250 \mathrm{fpm} \text {; } \\
\text { conveyor hp }=7 \mathrm{I} / 2\end{array}$ \\
\hline 108 & 1 & Front-end loader & 6 cubic yard capacity \\
\hline 109 & 1 & Reclaim hopfer & About 9 cubic yard capacity ( 6 tons) \\
\hline 110 & 1 & Vibrating feeder & Size $24^{\prime \prime} \times 5^{\prime}-a^{\prime \prime} ; 1 \mathrm{hp} ; 150 \mathrm{tph}$ \\
\hline 111 & 1 & Metal detector & To stop conveyor to allow tramp metal removal. \\
\hline 112 & 1 & Conveyor & $\begin{array}{l}36^{\prime \prime} \text { wide belt with Elexible sidewalls and cleats to allow } \\
\text { steep incline; speed }=200 \mathrm{fpm} ; 15 \mathrm{hp}\end{array}$ \\
\hline 113 & 1 & Baghouse dust collector & Bags discharge to bin (collector not selected) \\
\hline 114 & 1 & Faw coal storage bin & $18 \mathrm{ft}$ diameter; cone bottom; 120 ton capacity \\
\hline 115 & 1 & slide gate & Mechanical gear type; used for feeder maintenance \\
\hline 116 & 1 & Weigh feeder & $18^{\prime \prime}$ belt; $3 \mathrm{hp} ; \pm 1 \mathrm{I} / 2 \%$ accuracy by weight \\
\hline 117 & 1 & Diverter chute & $\begin{array}{l}\text { Allows feed to either coal pulverizer - gate manually } \\
\text { operated }\end{array}$ \\
\hline 118 & 2 & $\begin{array}{l}\text { Coal pulverizer } \\
\text { (1 operating and } \\
1 \text { standby) }\end{array}$ & Capacity $=13,600 \mathrm{ib} / \mathrm{hr}$ bowl mill; $150 \mathrm{hp}$ \\
\hline 119 & 1 & Mill Ean. & 75,000 scfm; 75 hp \\
\hline 120 & 1 & Air separator & Cyclone type \\
\hline
\end{tabular}


IV. MAJOR EQUIPMENT LIST (CONT'D.)

PROJECT: DEFINITION OF MODEL - SLURRY MIXING/DISTRIEUTION FACILITY

\begin{tabular}{|c|c|c|c|}
\hline $\begin{array}{l}\text { ITEM } \\
\text { NO. }\end{array}$ & $\begin{array}{l}\text { NO. } \\
\text { REQ'D. }\end{array}$ & DESCRIPTION & EQUIPMENT DATA \\
\hline 121 & 1 & Rotary valve & $1 \mathrm{hp}, 8^{\prime \prime}$ diameter \\
\hline 122 & 1 & Weigh zuger & $\begin{array}{l}5+\text { tph; prefeeder } h p=3 / 4 ; \text { conveyor } h p=1 / 4 ; \\
\pm 1 / 2 \% \text { accuracy }\end{array}$ \\
\hline 123 & 1 & Additive unloading Jum? & $60 \mathrm{gpm}$ \\
\hline 124 & 1 & Additive storage taik & $\begin{array}{l}10 \mathrm{ft} \text { diameter } x 20 \mathrm{ft} \text { long; about } 2200 \text { gallons capacity; } \\
\text { about one week's supply at } 0.5 \% \text { by weight of total mix }\end{array}$ \\
\hline 125 & 1 & Acditive feed pump & $0.5 \mathrm{gpm}$ \\
\hline 126 & 1 & Mix tank & $\begin{array}{l}12 \mathrm{ft} \text { diameter } \times 11 \mathrm{ft} \text { hish with } 3 \text { hp agitator for mixing } \\
\text { pulverized coal, 非 fuel oil and additive; } 9200 \text { gallon capacity }\end{array}$ \\
\hline 127 & 2 & $\begin{array}{l}\text { COM slurry pump } \\
: 1 \text { operating and } \\
1 \text { standby) }\end{array}$ & $45 \mathrm{gpm}$ \\
\hline 128 & 2 & CoM siurry storage tenik & $\begin{array}{l}64,500 \text { gallors eacli; one day"s plant production each; } \\
20 \mathrm{ft} \text { diameter } \mathrm{x} 3 \mathrm{Jt} \text { high }\end{array}$ \\
\hline 129 & 2 & CJM azitator & 50 hp each \\
\hline 130 & 1 & COM p.amp & $120 \mathrm{gpm}$ \\
\hline 131 & & Tank truck & \\
\hline 132 & & Railroad tank car & \\
\hline 133 & 1 & Euel ojl storage pump & $120 \mathrm{gpm}$ \\
\hline 134 & 2 & Fuel oil tanks & $\begin{array}{l}100,000 \text { gallons each; two tanks = approximately one week } \\
\text { of plant needs }\end{array}$ \\
\hline 135 & 2 & $\begin{array}{l}\text { Fuel oil feed pumfs } \\
\text { (1 operating and } \\
1 \text { standby) }\end{array}$ & $20 \mathrm{gpm}$ \\
\hline
\end{tabular}

NOTE: AIl capacities shown above are process flow rates required and do nos reflect equipnent rated sapacities. 
V. CONCEPTUAL DRAWINGS

Listed below are the General Arrangement Drawings and Material Flow Diagram developed for the subject model facility and they are included in this section.

Drawing No. Title

SK 92177-1 Material Flow

SK 92177-2 Plan of Plant

SK 92177-3 Sections

SK 92177-4 Sections 


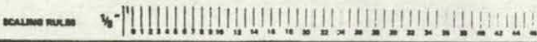
$\nabla 11111111111111111111111$. *.7! ! ! ! ! ! ! ! ! ! ! 1! ! !

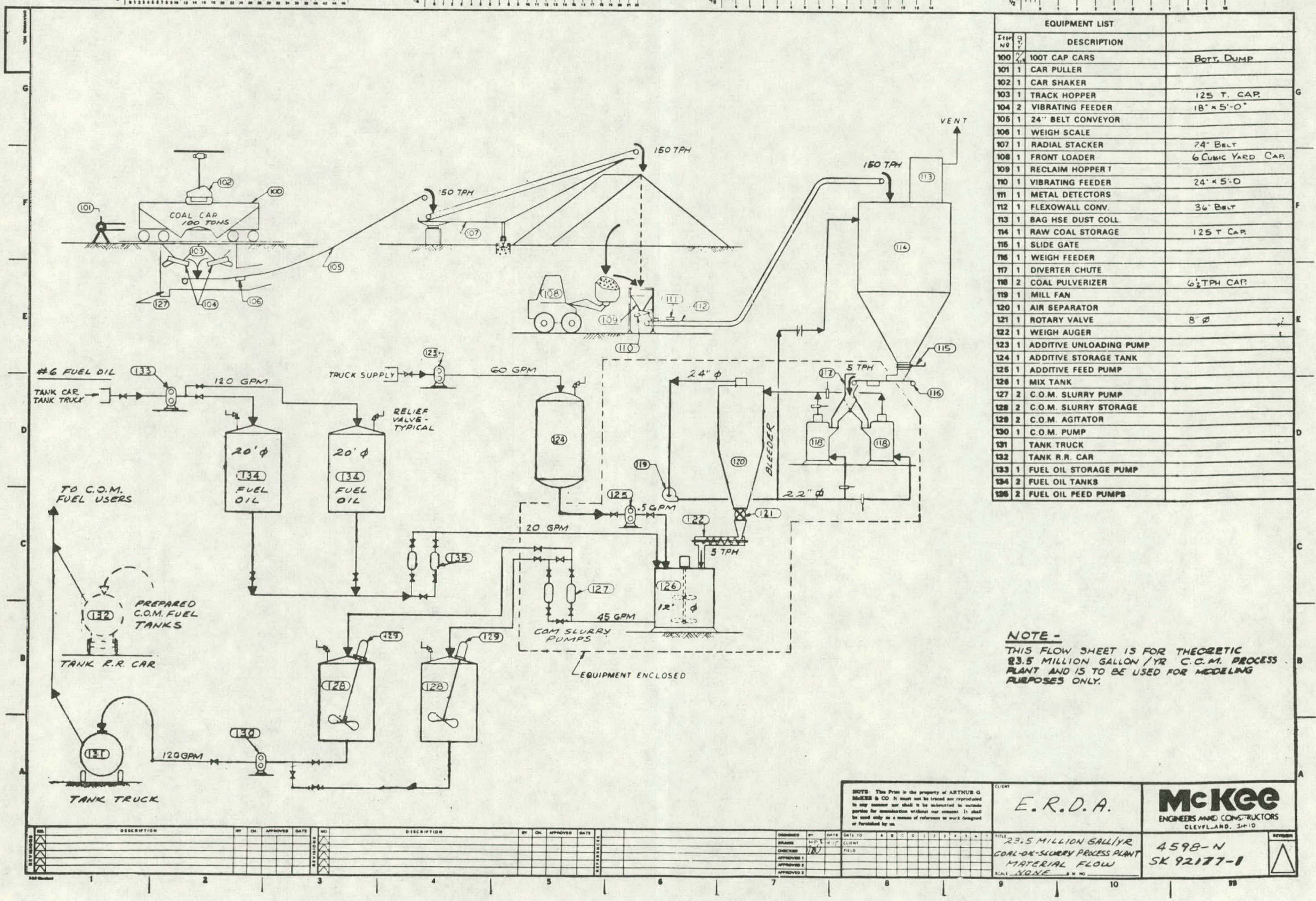




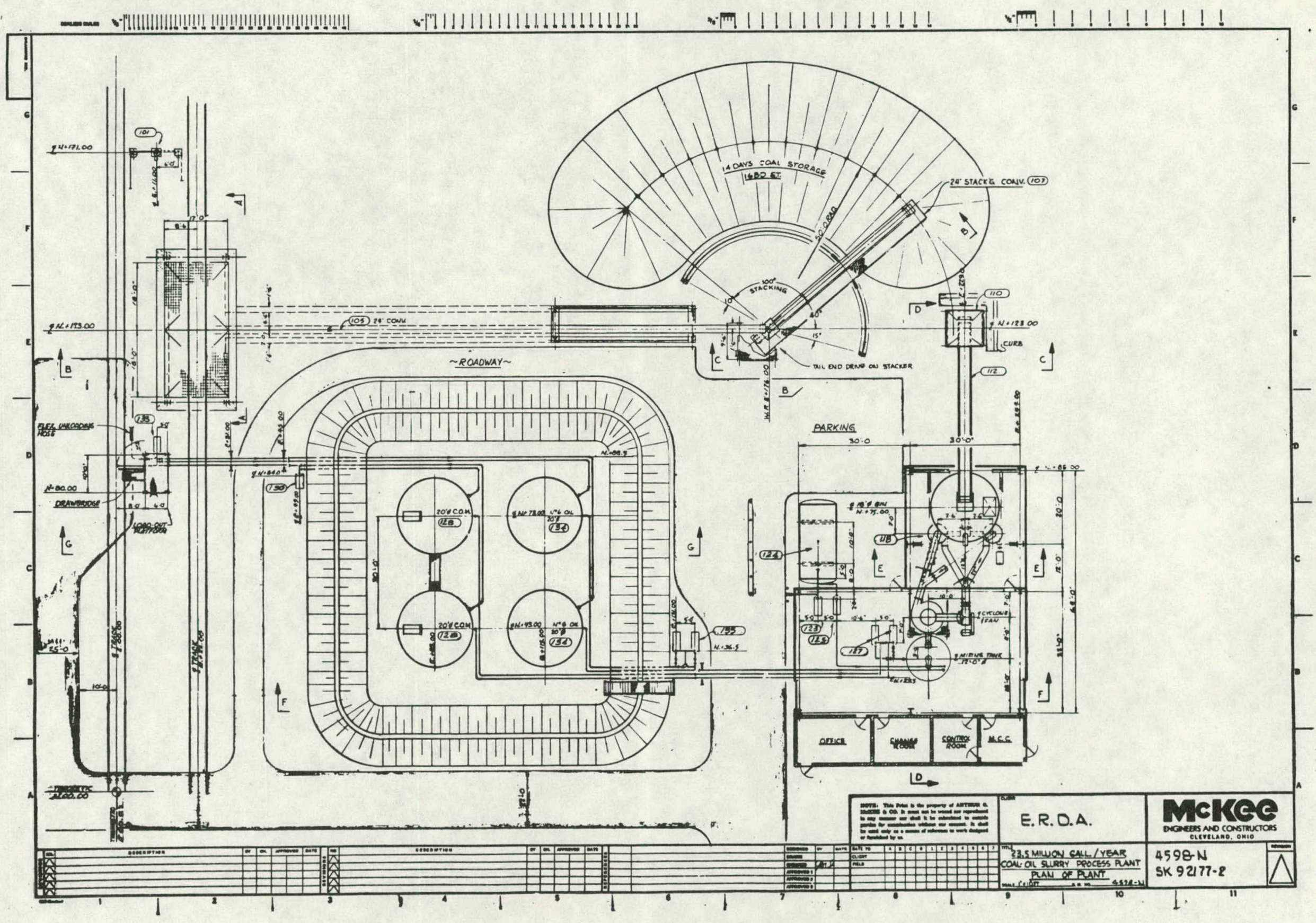




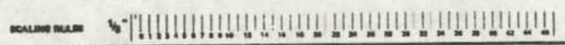
4.11111111111111111111111
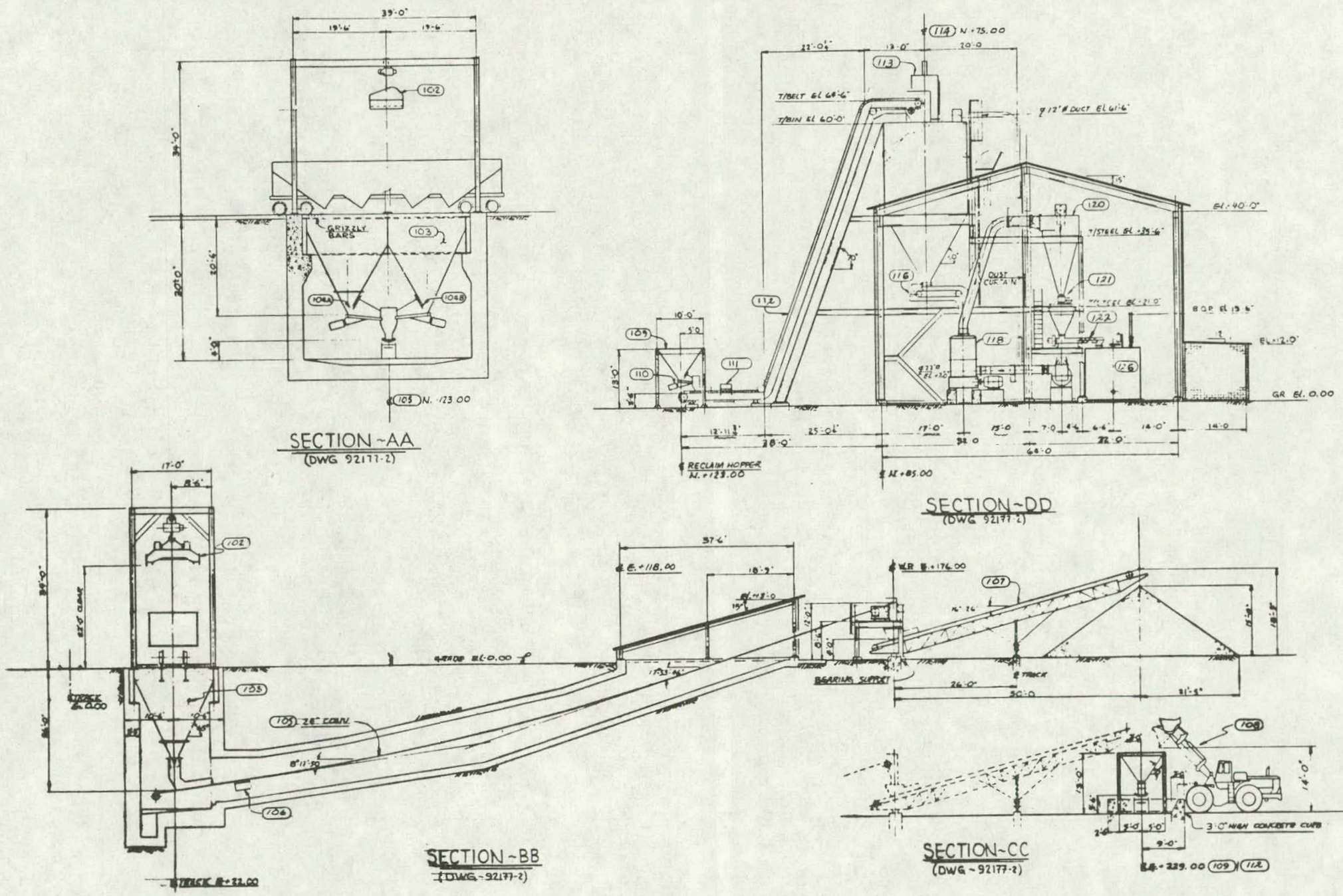

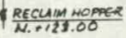

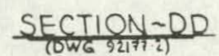
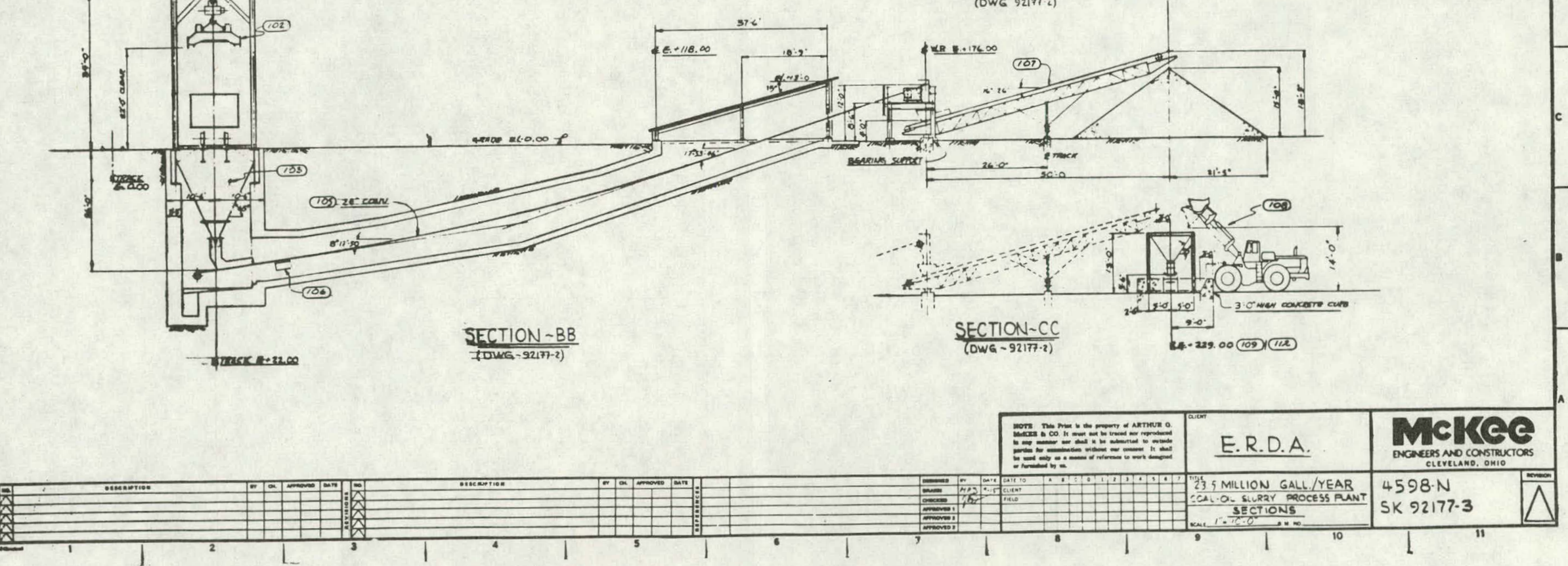


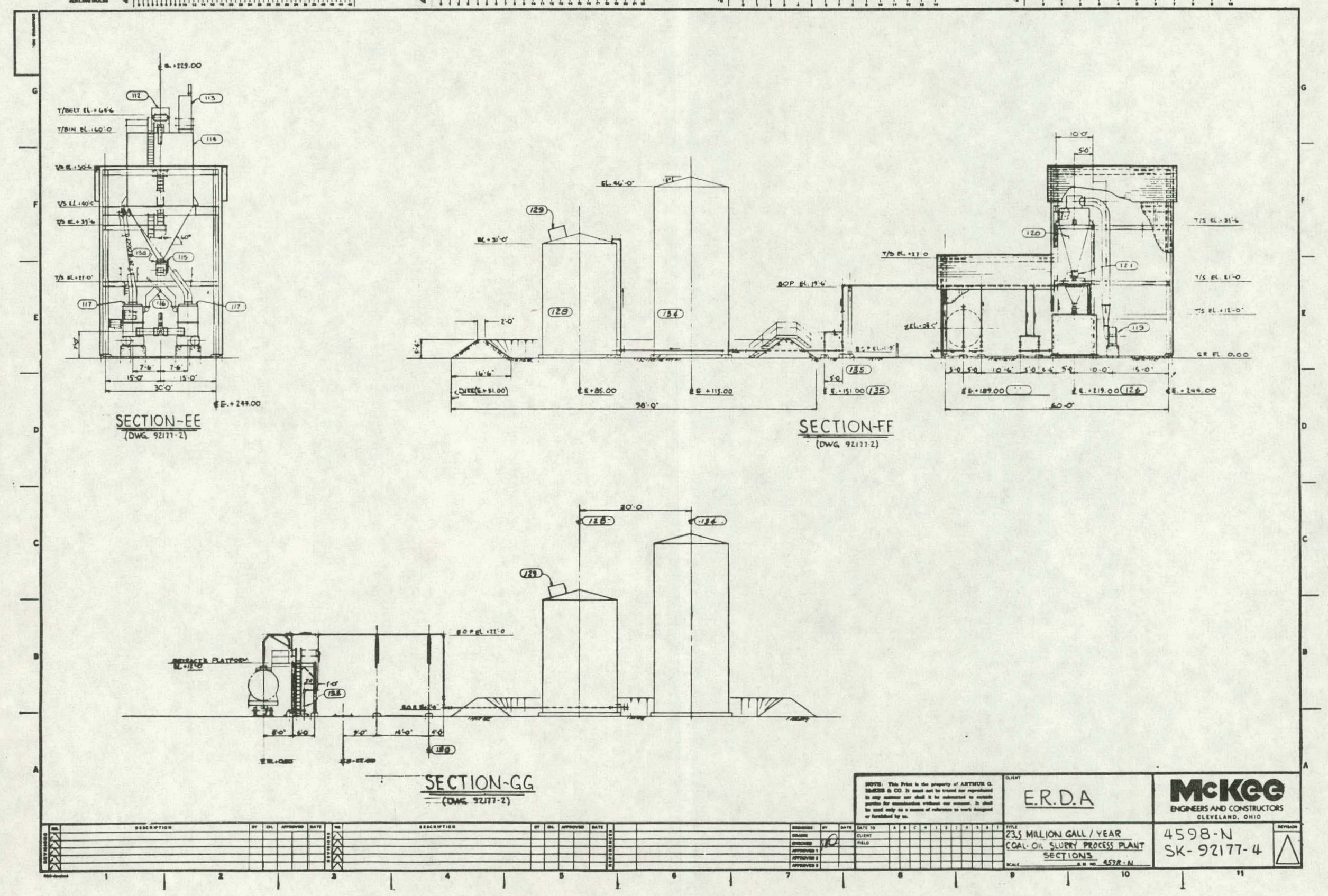

